\title{
Implementation Cooperative Learning Happy Cooking to Improve Social Emotional Skill Children Ages 5-6 Years
}

\author{
Safira Nurannisa Pulungan ${ }^{1}$, Tomas Iriyanto ${ }^{2}$, Sandy Tegariyani putri S. ${ }^{3}$ \\ ${ }^{123}$ State University of Malang, Malang, Indonesia
}

Corresponding e-mail:*tegariyanisandy@gmail.com

\begin{abstract}
Social emotional skill is one of important skill that need to improve in early years. Children with good social emotional skill would be good personality and be accepted in social environment. Purpose of this study to show how implementation of cooperative learning happy cooking to improve social emotional skill. This study using classroom action research methods, subject of this study are 5-6 years children at TK Al Muhajirin Malang. Result of this study are cooperative learning Happy Cooking with involving children to make simple food can improve social emotional skill likes cooperation with peers, follow the rules,patiently for the turn, showed their feeling, and showed positive feeling when do the activity. Suggestion from this study is cooperative learning happy cooking is one of alternative activity that can use to improve early childhood skill.
\end{abstract}

Key word: cooperative learning, happy cooking, social emotional skill

\section{NTRODUCTION}

Early childhood education should develop various aspects of development, namely aspects of moral development, physical, cognitive, language, and social emotional. However, in fact education in formal institutions is less attention to social aspects of emotional. This is shown when the learning process of children is still less able to cooperate, less obey the rules, and easily angry when playing.

According to Erikson's theory (Santrock, 2007: 46) there are 8 stages of child development that children pass through in their lives. Children aged 5-6 years are included in the transitional stages 3 and 4 . The stages, namely Initiative versus guilt and integrity versus inferiority

Initiative versus guilt is Erikson's third psychological stage. This stage relates early childhood stage, around the age of 3-5 years. It is at this point that the child feels a broad social world. To overcome the challenges of early childhood they must be active and their actions must have a purpose. At this stage, adults, parents, teachers and the environment are responsible and carry out the task of keeping them physically and psychically. Bringing a sense of responsibility requires initiative. Children develop a sense of guilt if they are not responsible or feel too anxious.

Integrity versus inferiority (Middle-Late Childhood) is the fourth psychological stage of Erikson. This stage occurs approximately during elementary school, from the age of six years to the age of puberty or early adolescence. At this stage the child is ready to accept the challenge of new things. They need opportunities for their physical, intellectual, and social fulfillment. They require a lot of interaction variations with others. The success and feeling of "I can do it" enhances his confidence. Children's initiative gets them in touch with many new experiences. As they enter primary school, they use their energies to master intellectual knowledge and skills. The final childhood is a time when children are most eager to learn, as their imagination grows. The dangers in elementary school are the emergence of feelings of inferiority, ineffectiveness and incompetence.

The stage explains that the social development of children at the age of 5-6 years through feelings of guilt if it can not be responsible for the task already given. So parents and teachers need to provide support so that children can be an initiative in dealing with problems. And in the next stage the child becomes excited about challenges and new things.

Ideally at the age of 5-6 years the emotional social development of children already shows start playing with peers and communicate well with the surrounding environment. Be polite and caring through words and deeds spontaneously (eg, say sorry, excuse, thank you). Create and follow rules. Expressing feelings, ideas with appropriate word choices when communicating. Have behaviors that reflect patience (want to wait turn, want to hear when others speak) to train discipline. Be able to protect themselves from violent experiments, including sexual assault and bullying (eg by shouting and / or running). 
Emotional social behavior expected from early childhood are good behaviors, such as discipline, independence, responsibility, confidence, honest, fair, faithful friend, loving nature to others, and have high tolerance. However, the emotional social skills of 5-6 years old students in Al Muhajirin Malang kindergarten still appear negative behavior, such as disrespect when talking to adults, do not want to cooperate with friends, impatient, disobedient, and irritable. This is unfortunate so that the need for completion so that when the child will enter high school does not have problems in the environment.

Seeing the gap that occurs, researchers try to make improvements that are on activities that can stimulate the emotional social capabilities of children. Based on the problems and causal factors that have been found, there is a need for an appropriate solution to the problem of emotional social ability. It is hoped that alternative solutions can stimulate and enhance children's emotional social abilities. There are 5 alternative solutions that are appropriate according to the researcher: 1) provide educative parenting for parents, 2) create a conducive and supportive environment for children, 3) group based learning, 4) provide guidance on proper spectacle and not to be seen, 5) Learn and play with interesting media.

Based on the above alternatives, the researcher chose to use group activities as an alternative that can help solve the problem. Using group or cooperative activities allows children to learn how to interact and work with each other, so that emotional social skills will develop. Therefore, the need for activities that are interesting, fun and not too difficult to understand by children so as to stimulate the emotional social capabilities of children. In essence, early childhood with the age of 5-6 years of learning and play activities, interesting and fun activities will make children participate happy and active in learning.

This is supported by some previous research. Meilani (2014) stated that "the ability to cooperate after following the cooking activities has undergone a good change. The change is seen once when the child interacts with a good friend in a group game or while they are playing alone. Children can be active in the process of learning activities, and children become interested and enthusiastic follow the game activities. In this research, cooking activity can develop social ability of children. These activities can be used individually and in groups. It has not yet been explained the emotional social capability indicator used in the study.

Iriyanto (2013) states that "the development of the sprout seed procedure is carried out as follows, stage 1 planning, phase 2 execution, stage 3 observation and reflection stage 4. Based on the study results concluded cooperative can improve children cognitive ability". In this study the learning used is cooperative learning but the ability developed is the cognitive ability.

Hossein \& Davoudi (2016) stated that "the results of path analysis show that team enjoyment with the coefficient of 0.418 has the highest effect on learning outcomes, teamwork with the coefficient of 0.205 has influenced learning outcomes, teamwork with variable pleasure teams and coefficients of 0.108 has affected results learn". In this study only apply group-based learning with the division of tasks based on large groups. Provision of motivation becomes the key to success targeted goals. Teamwork affects learning outcomes. If one member does not perform the task well, it will affect the group's learning outcomes.

Haryanti (2013) states that "the results of classroom action research using fun cooking activities show the percentage of emotional social ability success in the classification either with an average of $76 \%$. In cycle II shows excellent results, this is indicated by an increase in each indicator. Children can be in control of their turn, children are proud of their wealth, and can work together. The percentage of emotional social ability successes fall into the good classification of $89 \%$. This study further reinforces that cooking activities can be applied to improve children's emotional social abilities.

Playing cooperatively, game activities are done in groups, each child has a goal game. Children actively coordinate their activities, exchange toys, take certain roles and can maintain ongoing interactions. Aisha, et al (2010: 9-12) which states the age of 4-7 years; Children learn to develop emotional control skills with their peers. Children begin to learn how to communicate clearly, exchange information and explain their messages when their friends do not understand. He also began learning how to wait his turn to talk and play, and to share.

Results of research conducted by Slavin in Fadillah (2012: 190) mentioned that "the use of cooperative learning can improve student learning achievement and at the same time can improve social relationships, fosters the attitude of tolerance and appreciate the opinions of others. In addition, it can also meet the needs of students in critical thinking, problem solving, and integrating knowledge and experience "

The formation of group learning on students, it will increase social activity. This activity has a positive impact on students' emotional social development. Relation to early childhood 
education, cooperative learning is very helpful social development and cognitive emotional child. In other words, the child will learn to socialize, tolerate, and think and express his opinions well.

In some previous research results cooperative learning applied in high school, do not use type STAD, develop child's learning motivation, improve cognitive ability of child, activity in applying of cooperative learning also diverse. Cooperative learning can develop interaction among members. This research will be adjusted to the emotional social problems that occurred in TK Al Muhajirin Malang. This makes the researchers want to develop cooperative learning type Student Team Achievement Divisions (STAD) appropriate for the existing problems in kindergarten to improve children's emotional social skills through happy cooking day activities.

\section{METHODS}

This research uses Classroom Action Research design (PTK). Research using PTK because of problems that occur in learning in the classroom. This research this collaborative between researchers with teachers in schools, in the implementation of teachers in charge of carrying out activities that have been planned, and a friend of discussion. The data in this research is how the learning process using the activity of happy cooking day. Aspects observed are the development of emotional social skills and learning outcomes of children aged 5-6 years in kindergarten Al Muhajarin Malang. The source of this research data is B grade students with the number of 6 male students and 7 female students, and teachers in kindergarten $\mathrm{Al}$ Muhajarin Malang.After knowing the problems that occur in the field, the researchers who act as teachers make the research procedure. The details of the activities of these stages are as follows. (A) Cycle I, Planning, Execution, Observation, Reflection. (B) Cycles II, the stages in cycle II are the same as those in cycle I. Activity in cycle II is the improvement activity of cyclical I.

\section{RESULT}

Pre-action activities are observation activities conducted prior to the occurrence of an action research. Observation or observation data include matters relating to emotional social abilities especially the ability of the child in cooperating in groups, obeying the rules of the day, expressing feelings with emotion and patiently waiting their turn. (A) Learning conditions, learning conditions during pre-action of teachers using group-based learning. Children carry out individual assignments. Like the activities of writing, reading and drawing, children are accustomed to individuals in the task. Teachers do not use educational and media game tools in explaining learning, so the delivery of the material feels boring and unattractive to the child. (B) The condition of emotional social ability, based on the results of observation pre-action researcher finds the child's unattachedness in emotional social ability, especially on the ability of children in cooperating in groups because children are accustomed to individual, not obeying the rules of day-to-day such as not completing the task on time and do, Unable to express feelings with positive emotions such as temper tantrums and hit friends, and impatient in waiting for a turn. This is seen in the child's attitude from the beginning of learning to completion.

Emotional social skills on pre-action with 4 developing children and 9 underdeveloped children, average grade achievement rate 64.4. This average number indicates the achievement criteria is quite good. Classical achievement shows the number 30.7 with the number of children who grow as many as 4 people so that has not reached $80 \%$ achievement conditions.

Based on pre-action data the authors make improvements in the first cycle, which begins with the planning of the implementation of the activities of happy cooking day include: (1) Preparation of Daily Activity Plan, (2) Preparing tools and materials of happy cooking day activities on cycle 1: melon fruit, blender, milk , Sugar, and water, (3) Preparing research instruments to be used are observation sheets and field notes.implementation of cycle I will be held two meetings, ie on 23 February 2017 and 24 February 2017. Here is the exposure of data cycle I:

Learning Conditions, learning in cycle I apply the activities of happy cooking day to make melon juice to improve emotional social capabilities. At first, children who are accustomed to working individually after the implementation of this activity children are formed into a team and can work together. However, in the first cycle, cooperative learning has not been effective because of technical errors, namely power outages. This causes blinding activities to be unworkable, which leaves children frustrated that they can not make juices and children are not used to group activities. (2) Social Emotional Condition of the children of group B TK Al Muhajirin after the implementation of happy cooking day activity showed improvement. However, on the four indicators observed there are 5 children who have not been reached. Children are able to work with their teammates well, children can 
obey the rules of activity but there are some children who still violate and do as they please, children can patiently wait their turn but some children still there who can not wait at the time of the division of tools and materials that make Chaos between friends, and children can express feelings with positive expression well.

The emotional social abilities of the group's children TK Al Muhajirin Malang in working with a group of friends one-third of the time specified, obeying the rules of activity but not yet finished in time, expressing feelings with angry expression, happy and sad with good, and patiently waiting for the turn with the attitude of the face Flat has improved from pre-action results. But the child's achievement rate is still low. The average class shows the number 71.68 which shows good achievement. Out of 11 children there are 5 developing with achievement achievement class $45.4 \%$ and 6 not yet developed with achievement reach $54,54 \%$. Children are still unfamiliar with cooperative learning activities that require children to work together. So the level of classical achievement has not been $50 \%$.

The results of cycle I reflection: (1) The child is still unfamiliar with team-based learning, resulting in egocentric attitudes, (2) The use of a blender that only makes one between groups unconditioned when the yellow group blends and red waits on the table, (3) Are still unable to comply with the rules of activity such as incineration of milk, sugar and water but can be completed on time, (4) Group division at the one and two meetings equated to make the child less mingle and lead to discrimination, (5) The social emotional ability of the child has increased, But it needs improvement on the tools and materials that will be done in cycle II.

Implementation of cycle II will be held two meetings, ie on February 27, 2017 and February 28, 2017. Here is the exposure of data cycle II: (1) Learning Conditions when cycle II began to be conditioned, children are used and can work with the team. So that the activities of happy cooking day runs smoothly, (2) Social Emotional Capability Condition cycle II has increased. This can be seen from the level of achievement of students who are in accordance with the provisions. Children are able to cooperate well, do not appear keegosentrisan. Children can patiently wait their turn after using 2 blenders, the child focus on the activities of happy cooking day. The child can express a positive expression well with the appropriate expression. Children can obey the rules of activity to produce good juice

The result of observation of cycle II shows that the emotional social ability of $\mathrm{B}$ TK $\mathrm{Al}$ Muhajirin Malang children in cooperating with group friends and helping each other from the beginning to the end of the activity well, obeying the rules of activity from beginning to end, expressing feelings with positive expression correctly, and Eagerly awaiting their turn with a happy face improving from cycle I. Of the 10 developing children there were 5 who scored 100. The grade average indicates the number 84.4 which shows good achievement. The achievement of classical children also increased to $100 \%$. The activities of happy cooking day can improve emotional social ability, especially on the ability of children to cooperate, obey the rules, express expression and patiently wait their turn. Results of reflection on cycle II: (1) Implementation of cooperative learning of happy cooking day can increase emotional social capability of children, seen from percentage increase as much as $54,6 \%$, (2) Classical achievement indicates $100 \%$, this fulfill minimum standard, hence research (3) The use of 2 effective blenders for class conditioning and maximizing activities, (4) Cooperative learning of happy cooking day is appropriate to develop the emotional social abilities of children (outcomes of teacher interviews), (5) Children can obey the rules Activities from start to finish activities.

After the implementation of cooperative learning of happy cooking day in cycles I and II, it seems that the percentage increase of grade achievement is $54,6 \%$. From the results of research conducted on the second cycle, the learning cooperative happy cooking day to improve the social ability of the emotional group B Al Muhajirin Malang, said successful with the percentage of class achievement of $100 \%$ of the standard.

\section{DISCUSSION}

The activities of happy cooking day are carried out in two stages, ie phase I and cycle II. In its application the researchers adjusted the Salvin phase that has been simplified and adapted to the development of children aged 5-6 years. (2) teachers divide the children into 2 heterogeneous groups with 4-6 members in each group, (3) the teacher assigns the task, (4) the students work together to complete the task with teacher guidance, (5) teachers evaluate and reflect students' work

The activity begins with a circle time, the teacher does answering about the child's news today, and introduces the theme of the activity on this day that is happy cooking day. There are two large groups named with color names, group divisions using a secret box. Inside the secret box is a roll of colored paper that has been adapted to the number of students present that day. Children with the same color of rolls of 
paper will be a group. This is in accordance with Hairiyah theory (2013) which states STAD type cooperative learning is a form of learning by way of students learning and working in small groups whose members consist of four people with heterogeneous group structure.

Each group has its own team captain who has been appointed by the teacher. The team captain will distribute the tools and materials of the activity, at which point the members are instilled in their patience awaiting their turn. The children were then asked to peel and cut the melon into small pieces. Each member will collect the fruit in a container and asked to insert into the blender. Before blender each member has been given each task to include 3 tablespoons of milk, 3 tablespoons of sugar and water to taste. But there are still many who do not obey the rules, put milk and sugar too much. Blender is used only 1 so other groups have to wait if they want to make juice. This makes the class less conditioned.

The closing activity of this activity is that the captain distributes the finished melon juice and each member drinks the juice together. The teacher evaluates after the activity is completed. Do a question and answer about how to make melon juice, melon fruit smell, melon fruit flavor, melon juice and fruit difference before juicing, how the children feel when can make melon juice. In this activity the children are asked to express the perceived emotion with the appropriate expression.

After doing the reflection for cycle I, the researcher feel not satisfied because emotional social capability under study has not show minimal achievement, so the researcher hold cycle II. In cycle II using the same steps with cycle I, but researchers use different fruit, different division techniques and use 2 belender. Meeting I happy cooking day activities make apple juice. The core and closing activities are adapted to the activities of cycle I. At this first cycle II the children begin to understand the principles of teamwork, they already understand what will be done and should not be done. At the second meeting of the watermelon juice, the steps are the same as the first meeting. Improving the emotional social capabilities of children is very visible in this second cycle, not only the emotional social capabilities of cognitive, fine motor, language, art, and moral abilities are also emerging and developing. This happy cooking day cooperative learning is made to draw the attention of the child to get to know team-based learning, tolerance and affection.

In accordance with the results of previous research conducted by Meilani (2014) states that the implementation of fun cooking activities can improve the ability to cooperate and experience a good change. The change is seen once when the child interacts with a good friend in a group game or while they are playing alone. Children can be active in the process of learning activities, and children become interested and enthusiastic follow the game activities. This activity also helps teachers in introducing the various fruits, preparations and benefits to the children. Cooperative learning happy cooking day is very appropriately applied in group B TK Al Muhajirin Malang.

Ability that developed in cycle 1 after the implementation of cooperative learning happy cooking day. The child has not been able to express feelings through expression with good views from some children who still blurt out when not being captain by hitting and pinching his friends, but girls have been able to express positive emotions well. This is not in line with Aisha's theory, et al (2010: 9-12) which states the age of 4-7 years on the 2nd point; In this period parents need to start teaching the child to endure inappropriate behavior, focusing, and managing themselves.

In addition, the ability of children in cooperation began to show improvement seen from children can cooperate quarter of time specified. The ability of the child can patiently wait his turn also shows improvement, by waiting for unfinished friends to blend in the seat, but there are 2 children who are impatient and disturbing. According to Susanto (2011: 97) emotional social ability is the ability of children in social interaction with adults, recognize emotions, control emotions, set the mood, obey the rules, patience and can work together. Social and emotional development are two different aspects, but in reality each other affect each other. The researcher conducts cycle II activities to improve emotional social capabilities that have not been achieved.

In the second cycle found improvement in all indicators of children's emotional social abilities. Shown with the child has obeyed the rules given by the teacher well, no children who violate the rules of activity. Can be seen from children can cooperate and understand the duties of each member well. Children can do juice-making activities in collaboration with a group of friends. This is supported by play and game theories, social development of children occurs with five categories Padmonodewo (in Nugraha, 2012: 1.22-1.25) one of the categories of social development is to play cooperatively, the game activities are done in groups, each child has a goal game. Children actively coordinate their activities, exchange toys, take certain roles and can maintain ongoing interactions. 
The ability of the child to patiently wait his turn also increases. Viewed from the child can patiently wait his turn by waiting for friends who have not finished cutting and then help, because using 2 blender activities to the maximum. Children can express their feelings with positive expressions and not hurt their friends anymore. Children are very enthusiastic and enthusiastic about each meeting because of using different fruits. This is in accordance with the theory of Aisha, et al (2010: 9.12) aged 4-7 years on the 3rd point of the child learn to develop the skills to manage emotions with peers. Children begin to learn how to communicate clearly, exchange information and explain their messages when their friends do not understand. He also began learning how to wait his turn to talk and play, and to share. At the age of 5-6 years children can patiently wait their turn at the time of play and can share, this has been manifested in the activities of happy cooking day.

At the pre-action only 4 students were achieved and 9 students had not been reached, with the class achievement was $30.7 \%$ and the grade average was only 64.4 with good enough criteria. In the implementation of the cycle I, the emotional social capability of the child increased to 5 students and 6 students who had not been achieved, with the class achievement was $45, \%$ and the average class was 71.68 with good criteria. In the implementation of cycle II the emotional social capability of the child continues to increase to 10 students achieved all, with the achievement of the class is $100 \%$ and the average class 89.95 with very good criteria. The implementation of cooperative learning of happy cooking day has increased in every cycle with good result. This study stops in cycle II because all the emotional social abilities of children have increased and the achievement of classical children has met the achievement level standard which is more than $80 \%$.

\section{CONCLUSION}

Based on the results of research and discussion of exposure data that has been presented can be concluded that cooperative learning happy cooking day can improve the emotional social capabilities of children group B TK Al Muhajirn Malang, the following will be described penejelasannya. (1) Cooperative learning of happy cooking day is a learning that is designed to improve children's emotional social skills. This learning uses team-based strategies on the application of fruit juice drinks. In its application the researchers adjusted the Salvin phase that has been simplified and adapted to the development of children aged 5-6 years. The phase is: (a) the teacher performs the demonstration lesson, (b) the teacher divides the child into 2 heterogeneous groups with 4-6 members in each group, (c) the teacher assigns the task, (d) the students work together to complete the task with teacher guidance, (E) teachers evaluate and reflect students' work. This activity also helps teachers in introducing the various fruits, preparations and benefits to the children. Cooperative learning happy cooking day is very appropriately applied in group B TK Al Muhajirin Malang. (2) Based on the results of the research, the students' emotional social ability at pratindakan when compared with the implementation of cycle I and cycle II has increased significantly. It is known from the results of planning and implementation of learning dilaksankan by teachers. Happy cooking day activities can improve the ability of children in cooperation with a group of friends. Children can obey the rules from start to finish. Children can patiently wait their turn with a calm attitude when making juice activity. The child can express his feelings using appropriate and positive expressions.

\section{SUGGESTION}

Based on the results of research that has been implemented, shows that the application of cooperative learning happy cooking day can improve social social skills. As for suggestions that can be given as follows: (1) Teachers, In learning activities, teachers are expected to apply cooperative learning as a way of cooking day or alternative to improve the ability of early childhood. (2) Other Researcher, For further researcher who want to conduct research with the same topic is expected to add materials, tools and materials in the instrument used so that the research data can be more accurate.

\section{REFERENCES}

[1] Hairiyah, N., \& Jubaidah, J. (2017). Penentuan Formulasi Dan Umur Simpan Sosis Buah Dengan Penambahan Tepung Tapioka. Jurnal Teknologi Agro-Industri, 3(1).

[2] Haryanti, D., \& Budianta, D. Salni, 2013. Potensi beberapa jenis tanaman hias sebagai fitoremediasi logam timbal $(\mathrm{Pb})$ dalam tanah. Jurnal Penelitian Sains, 16(2), 52-58.

[3] Meilani, F., Purwanti, H., \& Suharno, B. (2014, October). Kandungan Protein, Lemak, Populasi Bakteri, Dan Sifat Organoleptik Pada Bakso Ikan Rucah Dengan Berbagai Dosis Bawang Putih (Allium Sativum). In Mathematics And Sciences Forum 2014. 
[4] Nugraha, A. (2012). Transforming tradition: A method for maintaining tradition in a craft and design context. Aalto University.

[5] Santrock, J. W., \& Santrock, J. W. (2007). Psikologi Pendidikan edisi kedua.
[6] Zare, M., Soleimani-Ahmadi, M., Davoodi, S. H., \& Sanei-Dehkordi, A. (2016). Insecticide susceptibility of Anopheles stephensi to DDT and current insecticides in an elimination area in Iran. Parasites \& vectors, 9(1), 571. 